\title{
1 Origin of Organic Carbon in the Topsoil of Wadden Sea Salt Marshes
}

2

3 Running head: Organic carbon origin in salt marshes

4

\section{5}

6 7

\section{Authors, affiliations:}

Peter Mueller ${ }^{*}$, Hai Thi Do ${ }^{\S}$, Kai Jensen and Stefanie Nolte* Hamburg, Ohnhorststr. 18, 22609 Hamburg, Germany ${ }^{\S}$ Authors contributed equally to the manuscript

\section{ABSTRACT}

Applied Plant Ecology, Institute of Plant Science and Microbiology, Universität

*Corresponding authors: stefanie.nolte@uni-hamburg.de; peter.mueller@uni-hamburg.de

Blue carbon ecosystems, including salt marshes, play an important role in the global carbon cycle because of their high efficiency to store soil organic carbon (OC). Few studies focus on the origin of OC stored in salt-marsh soils, which comes from either allochthonous or autochthonous sources. The origin, however, has important implications for carbon crediting approaches because the alternative fate of allochthonous OC (AllOC), i.e. if it had not accumulated in the Blue $\mathrm{C}$ ecosystem, is unclear. Here, we assessed the origin of OC in two mainland salt-marsh sites of the European Wadden Sea, analyzing $\delta^{13} \mathrm{C}$ of topsoil $(0-5 \mathrm{~cm})$ samples, freshly deposited sediment (allochthonous source), and of above- and belowground biomass of vegetation (autochthonous sources). We tested for effects of geomorphological factors, including elevation and the distance to sediment sources, and of livestock grazing, as the most important land-use form, on the relative contributions of allochthonous versus autochthonous sources to the topsoil OC stock. A negative effect of distance to the creek on the relative contribution of AllOC was found at only one of the two salt marshes, probably 
26 due to differences in micro-topography between the two salt marshes. Additionally, the

27 relative contribution of AllOC increased with increasing distance to the marsh edge in areas

28 without livestock-grazing, while it decreased in grazed areas. Our findings demonstrate that

29 spatial factors such as surface elevation and distance to a sediment source, which have been

30 found to determine the spatial patterns of sediment deposition, also are important factors

31 determining the relative contribution of AllOC to topsoil OC stocks of salt marshes.

32 Furthermore, we provide first evidence that livestock-grazing can reduce the relative

33 contribution of AllOC to the soil OC stock. These findings thereby yield important

34 implications for $\mathrm{C}$ crediting and land-use management.

35

36 KEY WORDS

37 stable isotopes, carbon sequestration, livestock grazing, habitat management, Blue carbon,

38 allochthonous, autochthonous, tidal wetland, North Sea 
Salt marshes and other tidal wetlands play an important role in climate change mitigation because they are more efficient at storing soil organic carbon (OC) than most terrestrial ecosystems (Chmura et al. 2003, Mcleod et al. 2011). The outstanding capacity of tidal wetlands for long-term carbon (C) sequestration has often been attributed to three main factors, namely high rates of OC input, reduced rates of decomposition, and constant burial of OC with rising sea level (Bridgham et al. 2006, Mcleod et al. 2011). Tidal wetlands are characterized by high rates of autochthonous net primary production, and they are effective in trapping OC from allochthonous marine or riverine sources (Duarte et al. 2013). Moreover, reduced conditions of wetland soils can inhibit microbial metabolism and slow down the decay of organic matter $(\mathrm{OM})$, such that $\mathrm{OC}$ can accumulate and remain stable over centuries and millennia in many tidal wetlands (Kirwan \& Megonigal 2013). As tidal wetland soils accrete vertically with rising sea level, they do not become $\mathrm{C}$ saturated like most terrestrial soils. Rates of $\mathrm{C}$ sequestration can therefore be maintained over long time scales, potentially millennia, as evident by deep, C-rich deposits found in tidal-wetland ecosystems worldwide (Mcleod et al. 2011).

The recognition of the important role these coastal ecosystems play in the global C cycle has led to the concept of 'Blue C' and a strong interest to include these ecosystems in C crediting programs (Herr et al. 2017). For instance, protection, restoration, or construction of Blue C ecosystems could be credited as greenhouse-gas-offset activities in the context of climate-change policy (Callaway et al. 2012, Needelman et al. 2018). Such measures, however, need to be based on a thorough understanding of the processes driving $\mathrm{C}$ sequestration in these ecosystems. The origin of OC in tidal wetland soils, i.e. allochthonous OC (AllOC) vs. autochthonous OC (AutOC), can have important implications for $\mathrm{C}$ crediting and greenhouse- 
gas-offset activities, because the alternative fate of AllOC, i.e. if it had not accumulated in the tidal wetland, is unclear. For instance, $\mathrm{C}$ credits for the sequestration of AllOC are only due in protection, restoration, or construction projects if it would have returned to the atmosphere in the project baseline scenario (Needelman et al. 2018). It is well established that the relative contribution of AllOC vs. AutOC to soil OC stocks can vary considerably across sites and regions (Middelburg et al. 1997, Bouillon et al. 2003). Furthermore, based on studies assessing patterns of C-stable isotope signatures in soils or sedimentary processes within sites, it can be expected that the geomorphology of tidal wetlands and land use play key roles in the relative importance of AllOC vs. AutOC (Ember et al. 1987, Chen et al. 2015, Kelleway et al. 2017, Mueller et al. 2017). Yet, estimates of the relative contributions of AllOC to soil OC stocks derived from such assessments have rarely been conducted. Numerous studies investigated which geomorphological factors affect the spatial pattern of sediment deposition in tidal wetlands, which is the main pathway for AllOC input. Those factors include surface elevation and distance to sediment sources (i.e. distance to the creek, distance to the marsh edge) (Fagherazzi et al. 2012). In general, lower elevations and closer proximity to the sediment source result in higher sediment deposition (Esselink et al. 1998, Temmerman et al. 2003, Chmura \& Hung 2004). Additionally, vegetation height, stem density, and other plant traits are factors known to increase sediment deposition (Morris et al. 2002, Fagherazzi et al. 2012).

Live-stock grazing is a common form of land use or habitat management throughout European salt marshes, but also in other regions, e.g. China and South America (Bakker et al. 2002, Di Bella et al. 2014, Yang et al. 2017). A large number of studies assessed the effects of livestock grazing on soil OC stocks, mineralization, and sequestration in tidal wetlands and produced a wide range of outcomes (Yu \& Chmura 2009, Olsen et al. 2011, Elschot et al. 2015, Davidson et al. 2017, Mueller et al. 2017). Because livestock grazing exerts strong 
control on vegetation dynamics in tidal wetlands, effects on the contribution of AllOC inputs to soil OC stocks can be expected. Specifically, livestock grazing reduces vegetation height (Elschot et al. 2013), and therefore sediment deposition rate might also decrease (Nolte et al. 2015), likely resulting in lower AllOC inputs. Grazing also affects biomass production (Morris \& Jensen 1998, Di Bella et al. 2014), which is the source of AutOC. Both reduction in aboveground biomass production (Morris \& Jensen 1998) and increases in belowground biomass production (Elschot et al. 2015) under livestock grazing have been reported. In a previous study we hypothesized that the contribution of AllOC could be reduced under high grazing pressures due decreased sediment trapping by shorter vegetation (Mueller et al. 2017). However, a systematic assessment and an understanding of livestock-grazing effects on the relative contribution of AllOC versus AutOC to soil OC stocks in tidal wetlands are yet missing.

The aim of the present study is to identify important spatial factors controlling the relative contributions of AllOC to topsoil $(0-5 \mathrm{~cm})$ OC stocks in two salt marshes at the Wadden Sea mainland coast of Germany. $\delta^{13} \mathrm{C}$ analyses were used to assess the origin of OC, as commonly used in coastal environments (e.g. Thornton \& McManus 1994, Kemp et al. 2010, Saintilan et al. 2013). We expect that the relative contribution of AllOC to the soil OC pool is driven by geomorphological factors and additionally mediated by livestock grazing. Specifically, we hypothesize (1) that a higher relative contribution of AllOC would be found in lower elevations within the tidal frame. We hypothesize (2) that the AllOC contribution would decrease with distance to potential sediment sources, namely the distance to creek and the distance to marsh edge. Lastly, we hypothesize (3) that livestock grazing decreases the relative contribution of AllOC. 
The study was conducted from Dec 2014 to Sep 2015 in two salt marshes at the mainland coast of the Schleswig-Holstein Wadden Sea National Park, Germany (Fig. 1 A). The salt marshes within the National Park cover an area of $\sim 130 \mathrm{~km}^{2}$, approximately half of which is used for livestock grazing (Stock et al. 2005, Esselink et al. 2017). Both study sites, Dieksanderkoog (DSK) and Sönke-Nissen-Koog (SNK), are minerogenic, shallow depositional salt marshes, exposed to tidal amplitudes of 3.0-3.4 $\mathrm{m}$ at a diurnal frequency. Soils in both sites have OM contents $<15 \%$ and are dominated by grain-sizes $<63 \mu \mathrm{m}(>70 \%$ silts and clays)(Mueller et al. 2019). Flooding of the extensive high-marsh platforms, that this study is restricted to, only occurs during storm events predominantly in winter (Müller et al. 2013a, Butzeck et al. 2015). In both sites, the presence of a rectangular network of creeks, ditches and levees reveal the anthropogenic origin of the salt marsh during land reclamation in the beginning of the $20^{\text {th }}$ century (Müller et al. 2013b). The DSK $\left(53^{\circ} 58^{\prime} \mathrm{N}, 8^{\circ} 53^{\prime} \mathrm{E}\right)$ is located in the southern part of the National Park at the mouth of the Elbe Estuary, while the SNK $\left(54^{\circ} 38^{\prime} \mathrm{N} .8^{\circ} 50^{\prime} \mathrm{E}\right)$ is situated in the north, ca. $35 \mathrm{~km}$ south of the Danish border (Fig. 1). Both sites were entirely grazed by sheep until 1988 and 1992 (SNK and DSK, respectively), when grazing was abandoned and only maintained at high stocking densities of $>10$ sheep ha Grazed and ungrazed treatments are located next to each other and separated by a straight main creek. In each treatment, sampling points were placed along short and long transects (Fig 1. B). The long transects covered a distance of $620 \mathrm{~m}$ (SNK) and $730 \mathrm{~m}$ (DSK) 
along the main creek and consisted of five sampling points, starting at the seaward edge of what is considered here as the anthropogenic high-marsh platform (distance to marsh edge = $0 \mathrm{~m})$. The long transects kept an almost constant distance to the main creek of $54 \mathrm{~m}$ at SNK and $62 \mathrm{~m}$ at DSK. Short transects ran perpendicularly to the main creek and consisted of five points with different distances to the main creek (3 - $104 \mathrm{~m}$ at SNK; 2 - $107 \mathrm{~m}$ at DSK). The central points of the short transects were also part of the long transects (Fig.1). This sampling design resulted in $\mathrm{N}=13$ sampling points per treatment and a total of $\mathrm{N}=52$ sampling points for both marsh sites. Surface elevation relative to the German ordnance datum $(\mathrm{NHN}=$ Normalhöhennull) of sampling points was measured using a laser leveling device (Trimble, Sunnyvale, California, USA) and a nearby fixed benchmark with known elevation.

\section{Sample collection}

We used C-stable isotope analysis to distinguish between AllOC and AutOC. To assess the $\delta^{13} \mathrm{C}$ of the AllOC source, freshly deposited sediments were collected using circular sediment traps (Temmerman et al. 2003, Nolte et al. 2013a, 2019). The sediment traps were built of plastic plates with an internal diameter of $19 \mathrm{~cm}$ and a rim of $3 \mathrm{~cm}$, and were equipped with a floatable lid to protect the deposited sediment in the trap from disturbances (Temmerman et al. 2003). Traps were fixed to the marsh surface with a plastic stick (Butzeck et al. 2015). Sediment traps were sampled within $24 \mathrm{~h}$ after two storm events during winter 2014/15. The high-marsh platform is only flooded during storm-induced high tides, so that sediment and AllOC deposition is restricted to these events (Müller et al. 2013a, Butzeck et al. 2015). As we assumed the $\delta^{13} \mathrm{C}$ of the freshly deposited sediment to be similar throughout the marsh, we only deployed sediment traps at five sampling points along the long transect and at two sampling points nearest to the creek in the two short transects in each treatment and site (Fig. 1), resulting in the total number of 28 sediment traps. In the following, we will only refer to 
the data of one sampling event in Dec 2014, when the majority of traps (27 out of 28) contained deposited material, after ensuring that no significant differences in C-stable isotope signatures exist between sampling events.

Above- and belowground plant biomass, as AutOC source, was sampled at all sampling points at the end of the growing season 2015. Aboveground biomass was harvested at each sampling position in an area of $100 \mathrm{~cm}^{2}$. Belowground biomass of the uppermost $(5$ $\mathrm{cm})$ soil layer was collected using a soil corer $(\varnothing 2.5 \mathrm{~cm})$. Dual cores were taken at each sampling position and samples were subsequently pooled. All samples were stored at $-20^{\circ} \mathrm{C}$ until processing for further analysis.

To assess the $\delta^{13} \mathrm{C}$ of soil OC, soil samples of the uppermost $5 \mathrm{~cm}$ soil layer were collected at all sampling positions using a soil corer $(\varnothing 2.5 \mathrm{~cm})$ in Dec 2014. Our study investigated the origin of OC only in the uppermost $5 \mathrm{~cm}$ of the soil, because belowground biomass is usually concentrated at this depth in mainland high marshes of the Wadden Sea (Bartholdy et al. 2014, Redelstein et al. 2018). Additionally, down-core ${ }^{13} \mathrm{C}$ fractionation through repeated microbial cycling of OC and preferential substrate utilization make conclusions concerning the OC origin increasingly difficult with soil depth (Mueller et al. 2019). Samples were transferred to the laboratory and stored at $-20^{\circ} \mathrm{C}$ until processing.

\section{Sample processing and analysis}

Deposited sediment and soil samples were dried at $60^{\circ} \mathrm{C}$ until no further weight loss was observed. Plant materials and potential other coarse organic debris was removed by passing the sample through a 2-mm sieve. Samples were ground and homogenized using pestle and mortar. Sub-samples $(1 \mathrm{~g})$ were treated with $10 \%$ hydrochloric acid to remove carbonates and again dried at $60^{\circ} \mathrm{C}$. Biomass samples were cleaned using tap water and given a final rinse with deionized water before drying at $60^{\circ} \mathrm{C}$. Dry biomass samples were ground and 
homogenized in a ball mill (Retsch, Haan, Germany). $\delta^{13} \mathrm{C}$ of dried and homogenized bulk soil OM, deposited sediment OM, and fresh above- and belowground biomass were determined using an isotope ratio mass spectrometer (Nu Horizon, $\mathrm{Nu}$ Instruments, Wrexham, UK). Samples were analyzed in tandem with both laboratory (BBOT 2,5-Bis-(5tert-butyl-2-benzo-oxazol-2-yl) thiophene) and international standards (IAEA-600 Caffeine). The precision of the isotopic analysis was $<0.1 \%$. The isotopic compositions of all samples are reported using the standard $\delta$-notation versus Vienna PeeDee Belemnite (VPDB) as parts per thousand (\%o).

The relative proportions of the AllOC and AutOC were determined by applying a two-end-member mixing model based on the stable isotope composition of OC (e.g. Hedges et al. 1988, Belicka and Harvey 2009):

$\mathrm{f}_{\mathrm{Al}}(\%)=\frac{\delta^{13} \mathrm{C}_{\text {Soil }}-\delta^{13} \mathrm{C}_{\mathrm{Au}}}{\delta^{13} \mathrm{C}_{\mathrm{Al}}-\delta^{13} \mathrm{C}_{\mathrm{Au}}}$

where: $\mathrm{f}_{\mathrm{Al}}(\%)$ is the percentage contribution of the $\mathrm{Al} \mathrm{OC}$ in soil; $\delta^{13} \mathrm{C}_{\text {Soil }}$ is $\delta^{13} \mathrm{C}$ measured in the soil; $\delta^{13} \mathrm{C}_{\mathrm{Au}}$ is $\delta^{13} \mathrm{C}$ of the AutOC source (plant biomass); and $\delta^{13} \mathrm{C}_{\mathrm{Al}}$ is $\delta^{13} \mathrm{C}$ of $\mathrm{Al}$ OC.

The calculated contributions of AllOC vs. AutOC sources depend on the type of plant biomass (i.e. above- vs. belowground biomass) considered in the mixing-model calculations. As the contributions of above- vs. belowground plant biomass to the soil OM pool were unknown, we calculated $\mathrm{f}_{\mathrm{Al}}(\%)$ under the assumption of three different end-member terms for $\mathrm{Au} \delta^{13} \mathrm{C}$ : (1) $\delta^{13} \mathrm{C}$ of the aboveground biomass (Model A), (2) $\delta^{13} \mathrm{C}$ of the belowground biomass (Model B), and (3) the calculated $\delta^{13} \mathrm{C}$ of a 1:1 mixed contribution of above- and belowground biomass (Model M).

\section{Statistical analyses}


212 Two-way ANOVAs were used to test for differences in the isotopic composition of sediment and soil between sites and treatments. To test if $\delta^{13} \mathrm{C}$ of AllOC in deposited sediment differs in response to distance to the marsh edge, linear regressions were used separately for each site. To test if $\delta^{13} \mathrm{C}$ of AllOC deposited in sediment traps positioned close to the creek differ from those positioned far from the creek, one-way ANOVAs were used separately for each site. Three-way ANOVA was used to test for the effects of site, treatment, and type of plant tissue (above- vs. belowground biomass) on plant $\delta^{13} \mathrm{C}$, and subsequent two-way ANOVAs were conducted to test for the effects of treatment and site on the $\delta^{13} \mathrm{C}$ of above- and belowground biomass separately. Tukey's HSD tests were used for pairwise comparisons. Normal distribution of residuals (as checked visually) and equal sample sizes across groups assured robustness for parametric testing (McGuinness 2002).

ANCOVA was conducted to test for effects of site, treatment, distance to marsh edge, distance to creek, and relative elevation (elevation in comparison to mean surface elevation at each site) on the relative contribution of AllOC to the soil. Only pairwise interactions of factors were considered in the models. As model simplification is an essential part of ANCOVA designs, the most insignificant parameters were dropped step by step, and as few parameters as possible were kept in the model (Crawley 2005). The more complex models were retained only if the p-value (ANOVA based) comparing the two models was $<0.05$ (Crawley 2005). To exclude that identified effects on the contribution of AllOC are artifacts autochthonous $\delta^{13} \mathrm{C}$ end members (i.e. aboveground, belowground, mixed). All analyses were carried out using the software package ' $R$ ' version 3.3.1 (The R Foundation for Statistical Computing 2016). 


\section{RESULTS}

$\delta^{13} \mathrm{C}$ of AllOC, AutOC, and soil samples

$\delta^{13} \mathrm{C}$ of AllOC in deposited sediment differed significantly between sites $\left(\mathrm{F}_{1,23}=88.6, \mathrm{p}<\right.$ 0.0001). AllOC was more depleted in $\delta^{13} \mathrm{C}$ at DSK $\left(-24.22 \%_{0} \pm 0.35 \%\right)$ vs. SNK $(-23.10 \%$ \pm $0.25 \%$ ) (Table 1). Within sites, no significant differences in $\delta^{13} \mathrm{C}$ of the AllOC were detected between grazed and ungrazed treatments (Table 1). There was no significant interaction effect of site and treatment on the $\delta^{13} \mathrm{C}$ of AllOC $\left(\mathrm{F}_{1,23}=0.7, \mathrm{p}>0.4\right) . \delta^{13} \mathrm{C}$ of AllOC did not differ in response to distance to the marsh edge (in each site: $\left.\mathrm{R}^{2}<0.25, \mathrm{p}>0.1\right) . \delta^{13} \mathrm{C}$ of AllOC in traps positioned close to the creek did not differ from those positioned far from the creek (DSK: $F_{1,6}=2.2, p>0.1 ;$ SNK: $\left.F_{1,6}=1.9, p>0.2\right)$. Therefore, the mean $\delta^{13} \mathrm{C}$ of each site was chosen for $\delta^{13} \mathrm{C}_{\mathrm{Al}}$ in Equation 1.

The $\delta^{13} \mathrm{C}$ values of AutOC differed between sites $\left(\mathrm{F}_{1,93}=17.1, \mathrm{p}<0.0001\right)$, treatments $\left(\mathrm{F}_{1,93}=11.6, \mathrm{p}<0.001\right)$, and type of plant tissue, i.e. above- vs. belowground biomass $\left(\mathrm{F}_{1,93}=\right.$ $5.9, \mathrm{p}<0.05)$. There was a significant interaction effect of treatment and type of plant tissue on $\delta^{13} \mathrm{C}$ of $\mathrm{AuOC}\left(\mathrm{F}_{1,93}=4.0, \mathrm{p}<0.05\right)$. Subsequent two-way ANOVAs showed the effects of site and treatment on $\delta^{13} \mathrm{C}$ of aboveground biomass, belowground biomass and the 1:1 mixed above- and belowground biomass (Table 1). The aboveground biomass $\delta^{13} \mathrm{C}$ values were significantly different between sites $\left(\mathrm{F}_{1,47}=11.5, \mathrm{p}<0.005\right)$, with $\delta^{13} \mathrm{C}$ being more depleted in DSK $(-27.72 \%$ $\pm 0.74 \%$ ) vs. SNK $(-26.65 \%$ $\pm 1.38 \%$ ) (Table 1). Treatment had no effect on $\delta^{13} \mathrm{C}$ of aboveground biomass, and there was also no interaction of site and treatment effect on the $\delta^{13} \mathrm{C}$ of aboveground biomass (Table 1$) . \delta^{13} \mathrm{C}$ values of belowground biomass were affected significantly by site $\left(\mathrm{F}_{1,46}=6.0, \mathrm{p}<0.05\right)$, being more depleted in DSK $\left(-27.00 \%\right.$ $\pm 1.05 \%$ ) vs. SNK $(-26.32 \%$ $\pm 1.24 \%$ ) (Table 1$) . \delta^{13} \mathrm{C}$ of belowground biomass were constantly more depleted under grazing $\left(\mathrm{F}_{1,46}=16.5, \mathrm{p}<0.001\right)$ at both sites. The interaction of site and treatment had no effect on belowground biomass $\delta^{13} \mathrm{C}$. Similarly, 
the 1:1 mixed biomass $\delta^{13} \mathrm{C}$ was affected significantly by site $\left(\mathrm{F}_{1,47}=15.8, \mathrm{p}<0.0005\right)$ and treatment $\left(\mathrm{F}_{1,47}=9.7, \mathrm{p}<0.01\right)$, but not by the interaction of site and treatment. These differences in $\delta^{13} \mathrm{C}$ between above- and belowground biomass, treatments, and sites did not allow using any sort of mean $\delta^{13} \mathrm{C}$ value for the autochtonous end-member term in mixing models. Instead, we used the specific $\delta^{13} \mathrm{C}$ values of above-, belowground, and mixed biomass of each sampling point for the respective mixing-model calculations (Equation 1). Soil OC had $\delta^{13} \mathrm{C}$ values varying from $-28.00 \%$ to $-23.24 \%$ and differed significantly by site $\left(\mathrm{F}_{1,48}=34.7, \mathrm{p}<0.001\right) . \delta^{13} \mathrm{C}$ of DSK soil OC $(-26.75 \%$ o $\pm 0.35 \%$ ) was more depleted than SNK soil OC $(-25.61 \%$ $\pm 0.85 \%)$. Treatments had an effect on soil OC $\delta^{13} \mathrm{C}$, $\left(\mathrm{F}_{1,48}=10.4, \mathrm{p}<0.01\right)$, with more depleted ${ }^{13} \mathrm{C}$ under grazing $\left(-26.49 \%_{0} \pm 0.95 \%\right)$ compared to ungrazed treatments $(-25.87 \%$ o $\pm 0.82 \%$ ) (Table 1$)$. There was no significant interaction effect between site and treatment on soil OC $\delta^{13} \mathrm{C}$ values (Table 1).

\section{Relative contribution of AllOC in salt-marsh topsoils}

The three mixing models in which different AutOC end-member assumptions (only aboveground plant biomass (A), only belowground plant biomass (B), or 1:1 mixed plant biomass (M)) were used to calculate contributions of AllOC to the salt-marsh topsoil OC yielded different results (Fig. 2). Depending on the model used, AllOC contributions in grazed treatments ranged from $17.72 \pm 3.85$ to $23.64 \pm 4.84(\%)$. In comparison, a higher range was found in ungrazed treatments (from $11.79 \pm 4.95$ to $38.99 \pm 5.31(\%)$ ). Here, we found that a mixing model using the aboveground $\delta^{13} \mathrm{C}$ resulted in much higher contributions of AllOC to the topsoil OC stock compared to using the belowground $\delta^{13} \mathrm{C}$ (Fig. 2).

The ANCOVA results for the three mixing models, which were based on different autochthonous OC end-member assumptions (see above) also differed (Table 2). For further interpretation, we therefore considered only those effects as robust which were found to be 
significant in at least two models (Table 2).The interaction effect between site and distance to the creek was found to be significant in Model A and Model M (Table 2). In DSK, we found the highest AllOC contributions close to the creek. With increasing distance to the creek, there was a steep drop until a more or less stable value was reached (Fig. 3 A). In contrast,

291 the contribution of AllOC in SNK showed a different pattern and remained constant with increasing distance to the creek (Fig. 3 A). The interaction between treatment and distance to the marsh edge also had significant effects on the contribution of AllOC in Model A and Model M (Table 2). Close to the marsh edge (0 to $300 \mathrm{~m}$ ), the percentages of AllOC contribution were quite similar between treatments (Fig. 4 A). In the area of greater distance to the marsh edge, however, we found opposite patterns for the two treatments. Here, the percentage of AllOC increased with increasing distance to the marsh edge in ungrazed treatments, while it decreased in grazed treatments (Fig. 4 A).

ANCOVAs assessing the effects of geomorphological factors and grazing on the autochthonous $\delta^{13} \mathrm{C}$ end members (i.e. aboveground, belowground, mixed biomass) showed neither interaction effects of distance to the marsh edge and treatment, nor of site and distance to the creek, excluding that the identified effects on the AllOC contribution to the 303 soil are artefacts driven by spatial variability in plant $\delta^{13} \mathrm{C}$ (Table A1). 


\section{DISCUSSION}

The present study assessed the relative contributions of AllOC to topsoil OC stocks in two salt-marsh sites of the European Wadden Sea. A large number of studies on the importance of AllOC in marsh soils have been performed (e.g. Boschker et al. 1999, Tanner et al. 2010, Saintilan et al. 2013, Chen et al. 2015, Van de Broek et al. 2018). However, estimates of the relative contribution of AllOC vs. AutOC to OC stocks have rarely been provided. This is possibly due to large uncertainties associated with the application of two-end-member mixing models, which were also encountered in the present study (see discussed below in 'Methodological considerations'). For instance, mean AllOC contributions to topsoil OC stocks of the high-marsh platforms ranged between 18 and $31 \%$ of total soil OC depending on autochthonous $\delta^{13} \mathrm{C}$ end-member assumptions. The central aim of our investigation was therefore not to provide accurate budgets of AllOC vs. AutOC contributions, but to identify important spatial factors influencing the balance of the two sources. Specifically, we hypothesized that surface elevation, distance to sediment sources, and livestock grazing negatively affect the relative contribution of AllOC to the soil OC stock. Our findings can provide partial support for these hypotheses because complex interactions between the assessed factors existed and seem to exert important control on the distribution pattern of AllOC.

Relative elevation as a single factor did not affect the relative contribution of AllOC to the topsoil. We did, however, identify a negative effect of distance to the creek on the relative contribution of AllOC to the topsoil. This effect was only found at DSK and not at SNK, which we attribute to differences in relative elevation patterns within sites, and more specifically, in patterns of levee formation along the main creek (Fig. 3 B). At SNK, sampling points closest to the main creek are characterized by the highest relative elevation. We argue that this natural levee along the creek restricts inundation of the marsh platform 
until tidal heights exceed the levee elevation, resulting in similar inundation frequencies and AllOC inputs across the marsh platform (Fig. 3). At DSK, by contrast, sampling points closest to the creek are lower than subsequent points with larger distance to the creek, leading to highest AllOC inputs close to the creek (Fig. 3). As previously hypothesized (Haines 1976, Ember et al. 1987, Middelburg et al. 1997), our findings provide evidence that geomorphological factors such as surface elevation and distance to the creek, which determine the spatial patterns of sediment deposition (Esselink et al. 1998, Temmerman et al. 2003, Chmura \& Hung 2004), also are important factors determining the relative contribution of AllOC to the topsoil OC stocks of salt marshes. Yet, our data do not allow assessing if variability in AuOC input contributed to this finding. For instance, biomass production in salt marshes is also strongly controlled by geomorphological factors, such as elevation, affecting both hydrology and nutrient supply (Morris et al. 2002, Kirwan \& Guntenspergen 2012). describing the proximity of a given point to a potential sediment and thus AllOC source. We indeed demonstrate a significant effect of distance to the marsh edge. This effect, however, differed significantly between grazed and ungrazed treatments (Table 2). Specifically, our data show increasing relative contributions of AllOC with distance to the marsh edge in ungrazed treatments, whereas the opposite pattern was found in the grazed treatments (Fig. 4 A). We argue that the unexpected increase of the AllOC contribution with distance to the marsh edge in ungrazed treatments can be explained by elevational patterns of the marsh platform that are typically found across Wadden Sea salt marshes and elsewhere. Landward decreases in elevation often result from ditching, diking, and grazing processes in salt marshes (Stock 2011, Müller-Navarra et al. 2016, Esselink et al. 2017) and were also found in the two sites investigated here (Fig, $4 \mathrm{~B}$ ). As a consequence, landward areas of the marsh platform are 
flooded first and potentially more frequently, thus explaining higher relative contributions of AllOC in the landward ungrazed treatments.

The mechanisms causing the opposite effect of distance to marsh edge on the relative contribution of AllOC to the topsoil in grazed treatments is unknown. However, we hypothesize that they relate to pronounced differences in grazing pressure between landward and seaward locations (Kiehl et al. 2001, Nolte et al. 2013b, Mueller et al. 2017). Because livestock tends to remain close to the freshwater source near the seawall (Kiehl et al. 2001), grazing pressure increases with distance to the marsh edge, which is also reflected in decreasing vegetation height and increasing soil bulk density with increasing distance to the marsh edge in our study sites (Nolte 2014, Mueller et al. 2017). At least three non-exclusive mechanisms, supported by literature, could explain lower relative AllOC contributions at high grazing pressures. First, grazing-induced reductions in vegetation height could lead to lower plantmediated sediment trapping (Morris et al. 2002, Fagherazzi et al. 2012) and thus AllOC input in (Yang et al. 2008, Mueller et al. 2017). Second, livestock grazing is known to increase belowground AutOC inputs through higher root production (Elschot et al. 2015), which would translate into lower relative contributions of AllOC. Third, grazing could lead to a more effective preservation of AutOC in the soil, thereby decreasing the relative contribution of AllOC. That is, grazing-induced soil compaction is known to lower soil oxygen availability and thus reduce microbial activity (Elschot et al. 2015, Mueller et al. 2017). However, recent studies from the North Sea region suggest AllOC inputs are highly resistant to decay, being old-aged materials that stabilized in the marine environment before entering the marsh OC pool (Van de Broek et al. 2018, Mueller et al. 2019). It therefore seems likely that primarily the decay of autochthonous $\mathrm{OM}$ is susceptible to grazing effects on oxygen availability and microbial activity. 
Although our findings cannot identify the mechanism(s) responsible for the observed grazing effect, they yield important implications for ecosystem management and $\mathrm{C}$ crediting. Recent meta-analyses and large-scale studies suggest livestock grazing has no effect on soil OC stocks of salt marshes (Davidson et al. 2017, Ford et al. 2019). Our study provides first evidence of grazing effects on the balance between allochthonous and autochthonous soil OC. Because it is uncertain if $\mathrm{C}$ credits are due for the sequestration of AllOC, livestock grazing may actually increase the $\mathrm{C}$ value of salt-marsh area, by reducing the relative contribution of AllOC to the soil OC stock. However, there are important caveats concerning these implications; our study did not quantify absolute rates of AllOC vs. AutOC input and accumulation, but only reports on the relative contributions of the two sources to the soil OC stock. Yet, the majority of studies concerned with grazing effects on salt-marsh $\mathrm{C}$ dynamics are likewise restricted to OC stock assessments, but did not quantify rates of sequestration (Davidson et al. 2017, but see Elschot et al. 2015). In addition, recent studies provide evidence of a more effective preservation of allochthonous OM inputs in marsh soils than in situ produced OM, leading to an increasing relative contribution of AllOC vs. AutOC with soil depth or time in NW European salt marshes (Van de Broek et al. 2018, Mueller et al. 2019). Future research therefore needs to assess whether the here identified grazing effects on the balance between AllOC and AutOC remain with increasing soil depth and are thus relevant for considerations on long-term $\mathrm{C}$ dynamics.

\section{Methodological considerations}

Large differences were found in the estimates of AllOC contribution when the three mixing model approaches based on different plant $\delta^{13} \mathrm{C}$ end-members assumptions were compared, particularly in the ungrazed treatments (Fig. 2). We therefore stress the importance to consider differences in the isotopic composition of different plant tissues in mixing-model 
approaches used to calculate the relative contributions of AllOC vs. AutOC, which is surprisingly left unconsidered in many studies (but see Kelleway et al. 2018). In the present study, we found large differences in $\delta^{13} \mathrm{C}$ between above- and belowground biomass (Table 1). Because the relative contribution of above- vs. belowground biomass to the top soil is unknown, also the absolute values presented here need to be considered with caution. Depending on the end-member assumptions used (i.e. Model A vs. B vs. M), calculated AllOC contributions to the topsoil can be as low as $0 \%$ in some sampling points (Fig. 4 A). This seems unrealistically low, and may point to the fact that the actual ratio of above- to belowground contributions to the soil OC pool diverge from the end-member assumption. For instance, it is reasonable to assume small aboveground and large belowground contributions under grazing, considering the negligible aboveground litter accumulation (Mueller et al. 2017). Indeed, Model B (assuming no aboveground contributions) yields more realistic AllOC contributions of $4 \%$ for the sampling points yielding a $0 \%$ in Model M (Fig. 4 A). Unless relative contributions of different plant tissues to the soil OC pool are known, simple two-end-member mixing models can only yield an approximation of AllOC vs. AutOC contributions to soil OC stocks. The main goal of this study was therefore not to calculate precise budgets of AllOC vs. AutOC inputs, but to identify important factors controlling their relative distributions. Here, we used three different assumptions for our autochthonous end members to assess the robustness of the results obtained. Above, we only discussed effects that were significant in at least two of the three models tested. Additionally, however, there were other significant effects that were only detected by one of the three models, which provide additional support for the factors identified to be important and discussed above. That is, negative effects of grazing, distance to the creek, and relative elevation on the relative contribution of AllOC to the top soil were additionally detected by Models A and M (Table 1). Furthermore, a significant interaction of grazing and relative 
elevation was detected by Model B, supporting the interpretation that the interaction effect of grazing and distance to the marsh edge is mediated by differences in surface elevation.

In order to exclude artifacts caused by spatial variability in $\delta^{13} \mathrm{C}$ of plant biomass (i.e. our autochthonous $\delta^{13} \mathrm{C}$ end members), we also tested for effects of site, treatment, distance to the marsh edge, distance to the creek, and relative elevation on the autochthonous $\delta^{13} \mathrm{C}$ end members used. We found neither interaction effects of distance to marsh edge and treatment, nor of site and distance to creek on the autochthonous $\delta^{13} \mathrm{C}$ end member, excluding that the identified interaction effects on the AllOC contribution are artifacts driven by spatial variability in the plant $\delta^{13} \mathrm{C}$ (Table A1).We argue that such sensitivity analyses are crucial to assess the reliability of conclusions derived from stable-isotope mixing-model approaches.

\section{Conclusions and perspective}

The present study partly supported previous research showing that more AllOC is found closer to the sediment sources and in lower elevations (Middelburg et al. 1997, Spohn et al. 2013, Hansen et al. 2017, Yuan et al. 2017). However, while previous studies have shown that the contribution of AllOC to soil OC varies among different zones of tidal marshes (Spohn et al. 2013) or across sites and regions (Middelburg et al. 1997, Hansen et al. 2017, Yuan et al. 2017), our study is the first to evaluate geomorphology and land-use effects on the small scale variability in the relative contribution of AllOC to soil OC stocks. Our findings demonstrate that spatial factors such as surface elevation and distance to a sediment source, which have been found to determine the spatial patterns of sediment deposition (Esselink et al. 1998, Temmerman et al. 2003, Chmura \& Hung 2004), also are important factors determining the relative contribution of AllOC to the topsoil OC stocks of salt marshes. Furthermore, we provide first evidence that livestock-grazing can reduce the relative contribution of AllOC to the soil OC stock. These findings could yield important implications 
453 for $\mathrm{C}$ crediting and land-use management. Future research is required to quantify absolute

454 rates of AllOC vs. AutOC inputs and to assess whether the here identified effects on the

455 balance between AllOC and AutOC remain with increasing soil depth and are thus relevant

456 for considerations on long-term C dynamics.

457

458

459

460

461

462

463

464

465

466

467

468

469

470

471 
473 We thank Dr. Christoph Reisdorff for his methodological advice and help with lab work. We

474 thank Dr. Martin Stock and our project partners of the Wadden Sea National Park Schleswig-

475 Holstein for cooperation. This project was funded by the Bauer-Hollmann Stiftung in the

476 framework of the research project INTERFACE (Interaction of fish, plants, carbon and

477 sediment: management and ecosystem functions of Wadden Sea salt marshes).

478

479

480

481

482

483

484

485

486

487

488

489

490 
Bartholdy J, Bartholdy AT, Kim D, Pedersen JBT (2014) On autochthonous organic production and its implication for the consolidation of temperate salt marshes. Mar Geol 351:53-57

Belicka LL, Harvey HR (2009) The sequestration of terrestrial organic carbon in Arctic Ocean sediments: A comparison of methods and implications for regional carbon budgets. Geochim Cosmochim Acta 73:6231-6248

497 Di Bella CE, Jacobo E, Golluscio RA, Rodríguez AM (2014) Effect of cattle grazing on soil salinity and vegetation composition along an elevation gradient in a temperate coastal salt marsh of Samborombón Bay (Argentina). Wetl Ecol Manag 22:1-13

500 Boschker HTS, de Brouwer JFC, Cappenberg TE (1999) The contribution of macrophyte-derived organic matter 501 to microbial biomass in salt-marsh sediments: Stable carbon isotope analysis of microbial biomarkers. Limnol 502 Oceanogr 44:309-319

503 Bouillon S, Dahdouh-Guebas F, Rao AVVS, Koedam N, Dehairs F (2003) Sources of organic carbon in 504 mangrove sediments: variability and possible ecological implications. Hydrobiologia 495:33-39

505 Bridgham SD, Megonigal JP, Keller JK, Bliss NB, Trettin C (2006) The carbon balance of North American 506 wetlands. Wetlands 26:889-916

507 Van de Broek M, D, Vandendriessche C, Poppelmonde D, Merckx R, Temmerman S, Govers G (2018) Long508 term organic carbon sequestration in tidal marsh sediments is dominated by old-aged allochthonous inputs in a 509 macrotidal estuary. Glob Chang Biol 24:2498-2512

510 Butzeck C, Eschenbach A, Gröngröft A, Hansen K, Nolte S, Jensen K (2015) Sediment deposition and accretion 511 rates in tidal marshes are highly variable along estuarine salinity and flooding gradients. Estuaries and Coasts $512 \quad 38: 434-450$

513 Callaway J, Callaway JC, Borgnis EL, Turner RE, Milan CS (2012) Carbon sequestration and sediment 514 accretion in San Francisco Bay tidal wetlands. 35:1163-1181

515 Chen S, Torres R, Goñi MA (2015) The Role of Salt Marsh Structure in the Distribution of Surface Sedimentary 516 Organic Matter. Estuaries and Coasts 39:108-122

517 Chmura GL, Anisfeld SC, Cahoon DR, Lynch JC (2003) Global carbon sequestration in tidal, saline wetland 518 soils. Global Biogeochem Cycles 17:22-1-22-11

519 Chmura GL, Hung GA (2004) Controls on salt marsh accretion: A test in salt marshes of Eastern Canada. 520 Estuaries 27:70-81

521 Crawley M. (2005) Statistics: An Introduction using R. John Wiley, Sons Ltd: West Sussex

522 Davidson KE, Fowler MS, Skov MW, Doerr SH, Beaumont N, Griffin JN (2017) Livestock grazing alters 523 multiple ecosystem properties and services in salt marshes: a meta-analysis. J Appl Ecol 54:1395-1405

524 Duarte CM, Losada IJ, Hendriks IE, Mazarrasa I, Marba N (2013) The role of coastal plant communities for 525 climate change mitigation and adaptation. Nat Clim Chang 3:961-968

526 Elschot K, Bakker JP, Temmerman S, Van De Koppel J, Bouma TJ (2015) Ecosystem engineering by large 527 grazers enhances carbon stocks in a tidal salt marsh. Mar Ecol Prog Ser 537:9-21

528 Elschot K, Bouma TJ, Temmerman S, Bakker JP (2013) Effects of long-term grazing on sediment deposition 529 and salt-marsh accretion rates. Estuar Coast Shelf Sci 133:109-115

530 Ember LM, Williams DF, Morris JT (1987) Processes that influence carbon isotope variations in salt marsh 531 sediments. Mar Ecol - Prog Ser 36:33-42 
Esselink P, Dijkema KS, Reents S, Hageman G (1998) Vertical Accretion and Profile Changes in Abandoned Man-Made Tidal Marshes in the Dollard Estuary, the Netherlands. J Coast Res 14:570-582

Esselink P, van Duin W., Bunje J, Cremer J, Folmer E., Frikke J, Glahn M, de Groot A., Hecker N, Hellwig U, Jensen K, Körber P, Petersen J, Stock M (2017) Salt marshes. In: Wadden Sea Quality Status Report 2017. Eds.: Kloepper S. et al., Common Wadden Sea Secretariat, Wilhelmshaven, Germany. Last updated 21.12.2017.

537 Downloaded 29.05.2018. qsr.waddensea-worldheritage.org/reports/salt-marshes

538 Fagherazzi S, Kirwan ML, Mudd SM, Guntenspergen GR, Temmerman S, Rybczyk JM, Reyes E, Craft C,

539 Clough J (2012) Numerical models of salt marsh evolution: Ecological, geormorphic, and climatic factors. Rev 540 Geophys 50:1-28

Ford H, Garbutt A, Duggan-Edwards M, Pagès JF, Harvey R, Ladd C, Skov MW (2019) Large-scale predictions of salt-marsh carbon stock based on simple observations of plant community and soil type. Biogeosciences $543 \quad 16: 425-436$

544 Haines EB (1976) Stable carbon isotope ratios in the biota, soils and tidal water of a Georgia salt marsh. Estuar 545 Coast Mar Sci 4:609-616

546 Hansen K, Butzeck C, Eschenbach A, Gröngröft A, Jensen K, Pfeiffer EM (2017) Factors influencing the 547 organic carbon pools in tidal marsh soils of the Elbe estuary (Germany). J Soils Sediments 17:47-60

548 Hedges JI, Clark WA, Cowie GL (1988) Organic matter sources to the water column and surficial sediments of 549 a marine bay. Limnol Oceanogr 33:1116-1136

550 Herr D, von Unger M, Laffoley D, McGivern A (2017) Pathways for implementation of blue carbon initiatives. 551 Aquat Conserv Mar Freshw Ecosyst 27:116-129

552 Kelleway JJ, Mazumder D, Baldock JA, Saintilan N (2018) Carbon fractionation in mangrove Avicennia marina 553 has implications for food web and blue carbon research. Estuar Coast Shelf Sci 205:68-74

Kelleway JJ, Saintilan N, Macreadie PI, Baldock JA, Ralph PJ (2017) Sediment and carbon deposition vary among vegetation assemblages in a coastal salt marsh. Biogeosciences 14:3763-3779

Kemp AC, Vane CH, Horton BP, Culver SJ (2010) Stable carbon isotopes as potential sea-level indicators in salt marshes, North Carolina, USA. The Holocene 20:623-636

558 Kiehl K, Esselink P, Gettner S, Bakker JP (2001) The Impact of Sheep Grazing on Net Nitrogen Mineralization 559 Rate in Two Temperate Salt Marshes. Plant Biol 3:553-560

560 Kirwan ML, Guntenspergen GR (2012) Feedbacks between inundation, root production, and shoot growth in a 561 rapidly submerging brackish marsh. J Ecol 100:764-770

562 Kirwan ML, Megonigal JP (2013) Tidal wetland stability in the face of human impacts and sea-level rise. 563 Nature 504:53-60

McGuinness KA (2002) Of rowing boats, ocean liners and tests of the ANOVA homogeneity of variance 565 assumption. Austral Ecol 27:681-688

Mcleod E, Chmura GL, Bouillon S, Salm R, Björk M, Duarte CM, Lovelock CE, Schlesinger WH, Silliman BR (2011) A blueprint for blue carbon: toward an improved understanding of the role of vegetated coastal habitats in sequestering CO2. Front Ecol Environ 9:552-560

569 Middelburg JJ, Nieuwenhuize J, Lubberts RK, Plassche O Van De (1997) Organic Carbon Isotope Systematics of Coastal Marshes. Estuar Coast Shelf Sci 45:681-687

571 Morris JT, Jensen A (1998) The carbon balance of grazed and non-grazed Spartina anglica saltmarshes at 572 Skallingen, Denmark. J Ecol 86:229-242

573 Morris JT, Sundareshwar P V, Nietch CT, Kjerfve B, Cahoon DR (2002) Responses of coastal wetlands to 574 rising sea level. Ecology 83:2869-2877 
Mueller P, Granse D, Nolte S, Do HT, Weingartner M, Hoth S, Jensen K (2017a) Top-down control of carbon sequestration: Grazing affects microbial structure and function in salt marsh soils: Grazing. Ecol Appl 27:14351450

Mueller P, Ladiges N, Jack A, Schmiedl G, Kutzbach L, Jensen K, Nolte S (2019) Assessing the long-term carbon-sequestration potential of the semi-natural salt marshes in the European Wadden Sea. Ecosphere 10:e02556

Müller-Navarra K, Milker Y, Schmiedl G (2016) Natural and anthropogenic influence on the distribution of salt marsh foraminifera in the bay of Tümlau, German North Sea. J Foraminifer Res 46:61-74

Müller F, Struyf E, Hartmann J, Wanner A, Jensen K (2013a) A comprehensive study of silica pools and fluxes in Wadden Sea salt marshes. Estuaries and Coasts 36:1150-1164

Müller F, Struyf E, Hartmann J, Weiss A, Jensen K (2013b) Impact of grazing management on silica export dynamics of Wadden Sea saltmarshes. Estuar Coast Shelf Sci 127:1-11

Needelman BA, Emmer IM, Emmett-Mattox S, Crooks S, Megonigal JP, Myers D, Oreska MPJ, McGlathery K (2018) The Science and Policy of the Verified Carbon Standard Methodology for Tidal Wetland and Seagrass Restoration. Estuaries and Coasts 41:2159-2171

Nolte S (2014) Grazing as a nature-management tool. Diss Univ Groningen, Netherlands

Nolte S, Butzeck C, Baldwin AH, Felton GK, Jensen K (2019) Efficiency of Varying Sediment Traps under Experimental Conditions Simulating Tidal Inundations. J Coast Res

Nolte S, Esselink P, Bakker JP, Smit C (2015) Effects of livestock species and stocking density on accretion rates in grazed salt marshes. Estuar Coast Shelf Sci 152:109-115

Nolte S, Koppenaal EC, Esselink P, Dijkema KS, Schuerch M, De Groot A V, Bakker JP, Temmerman S (2013a) Measuring sedimentation in tidal marshes: A review on methods and their applicability in biogeomorphological studies. J Coast Conserv 17:301-325

Nolte S, Müller F, Schuerch M, Wanner A, Esselink P, Bakker JP, Jensen K (2013b) Does livestock grazing affect sediment deposition and accretion rates in salt marshes? Estuar Coast Shelf Sci 135:296-305

Olsen YS, Dausse A, Garbutt A, Ford H, Thomas DN, Jones DL (2011) Cattle grazing drives nitrogen and carbon cycling in a temperate salt marsh. Soil Biol Biochem 43:531-541

Redelstein R, Dinter T, Hertel D, Leuschner C (2018) Effects of inundation, nutrient availability and plant species diversity on fine root mass and morphology across a saltmarsh flooding gradient. Front Plant Sci 9:1-15

Saintilan N, Rogers K, Mazumder D, Woodroffe C (2013) Allochthonous and autochthonous contributions to carbon accumulation and carbon store in southeastern Australian coastal wetlands. Estuar Coast Shelf Sci 128:84-92

Spohn M, Babka B, Giani L (2013) Changes in soil organic matter quality during sea-influenced marsh soil development at the north sea coast. Catena 107:110-117

Stock M (2011) Patterns in surface elevation change across a temperate salt marsh platform in relation to sealevel rise. Coastline Reports 17:33-48

Stock M, Gettner S, Hagge M, Heinzel K, Kohlus J, Stumpe H (2005) Salzwiesen an der Westküste von Schleswig-Holstein 1988-2001. Schriftenreihe des Nationalparks Schleswig-Holsteinisches Wattenmeer

Tanner BR, Uhle ME, Mora CI, Kelley JT, Schuneman PJ, Lane CS, Allen ES (2010) Comparison of bulk and compound-specific $\delta 13 \mathrm{C}$ analyses and determination of carbon sources to salt marsh sediments using n-alkane distributions (Maine, USA). Estuar Coast Shelf Sci 86:283-291 
Temmerman S, Govers G, Wartel S, Meire P (2003) Spatial and temporal factors controlling short-term sedimentation in a salt and freshwater tidal marsh, Scheldt estuary, Belgium, SW Netherlands. Earth Surf

618 Process Landforms 28:739-755

Thornton SF, McManus J (1994) Application of Organic Carbon and Nitrogen Stable Isotope and C/N Ratios as Source Indicators of Organic Matter Provenance in Estuarine Systems: Evidence from the Tay Estuary, Scotland. Estuar Coast Shelf Sci 38:219-233

Yang SL, Li H, Ysebaert T, Bouma TJ, Zhang WX, Wang YY, Li P, Li M, Ding PX (2008) Spatial and temporal variations in sediment grain size in tidal wetlands, Yangtze Delta: On the role of physical and biotic controls. Estuar Coast Shelf Sci 77:657-671

Yang Z, Nolte S, Wu J (2017) Tidal flooding diminishes the effects of livestock grazing on soil micro-food webs in a coastal saltmarsh. Agric Ecosyst Environ 236:177-186

Yu OT, Chmura GL (2009) Soil carbon may be maintained under grazing in a St Lawrence Estuary tidal marsh.Environ Conserv 36:312-320 


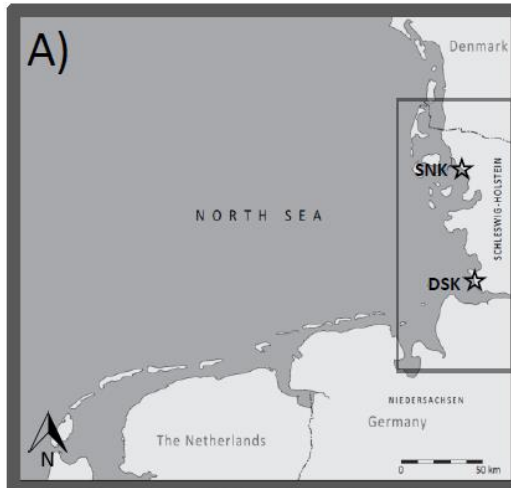

B)

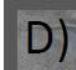

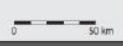

DSK

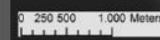
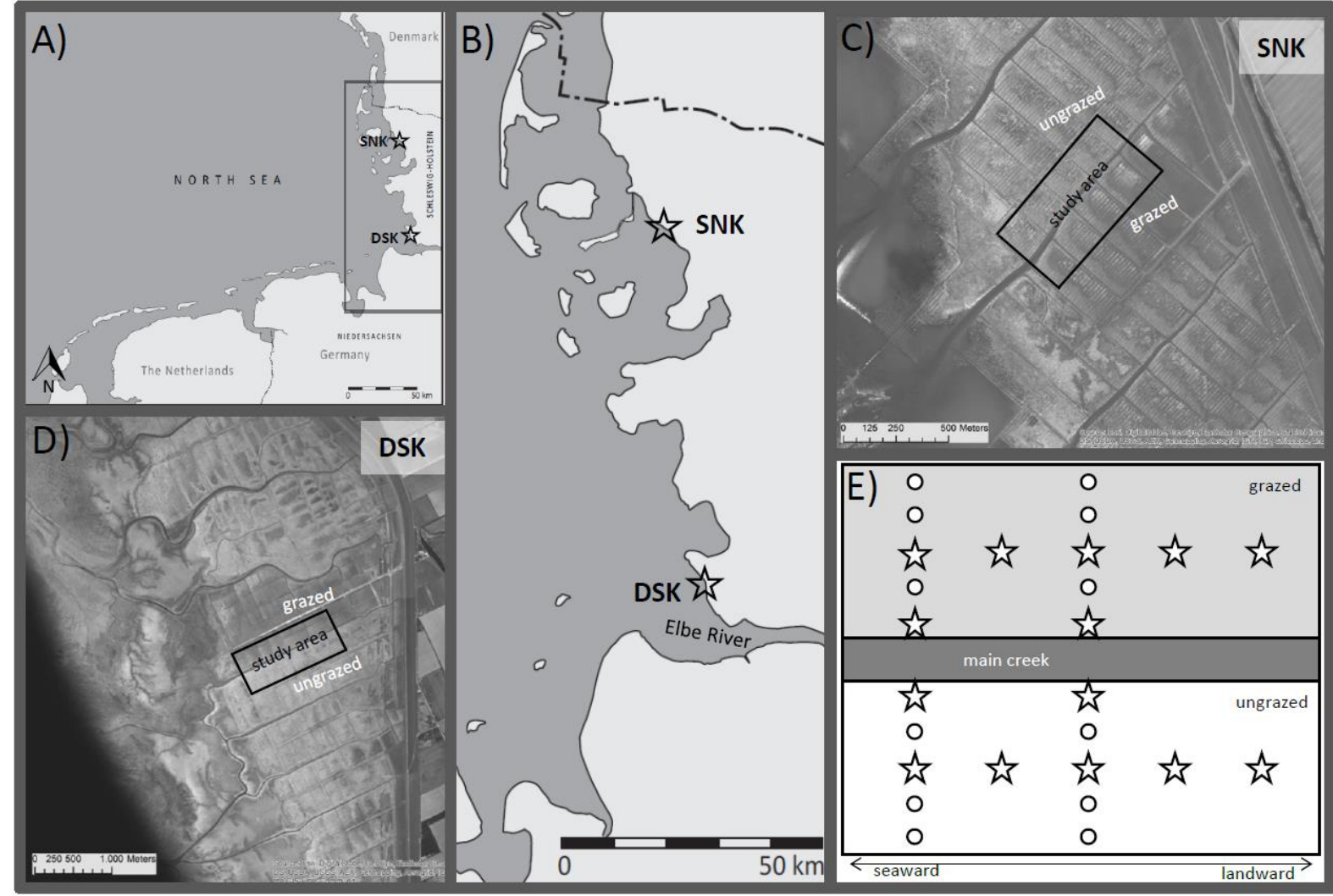

Figure $1(\mathbf{A}+\mathbf{B})$ Location of the study sites Sönke-Nissen-Koog (SNK) and Dieksanderkoog (DSK) within the Wadden Sea area. (C + D) Aerial photos of the study sites. (E) Sampling design: sampling points were organized along short transects (distance to the creek) and long transects (distance to the edge of the anthropogenic high-marsh platform) in grazed vs. ungrazed treatments. Soil and biomass samples were collected at all points, while deposited sediment samples were only collected at points marked with star symbols. Aaerial photos source: Esri, DigitalGlobe, GeoEye, Earthstar Geographics, CNES/Airbus CS USDA, USGS, AEX, Getmapping, Aerogrid, IGN, IGP, swisstopo, and the GIS User Community. 


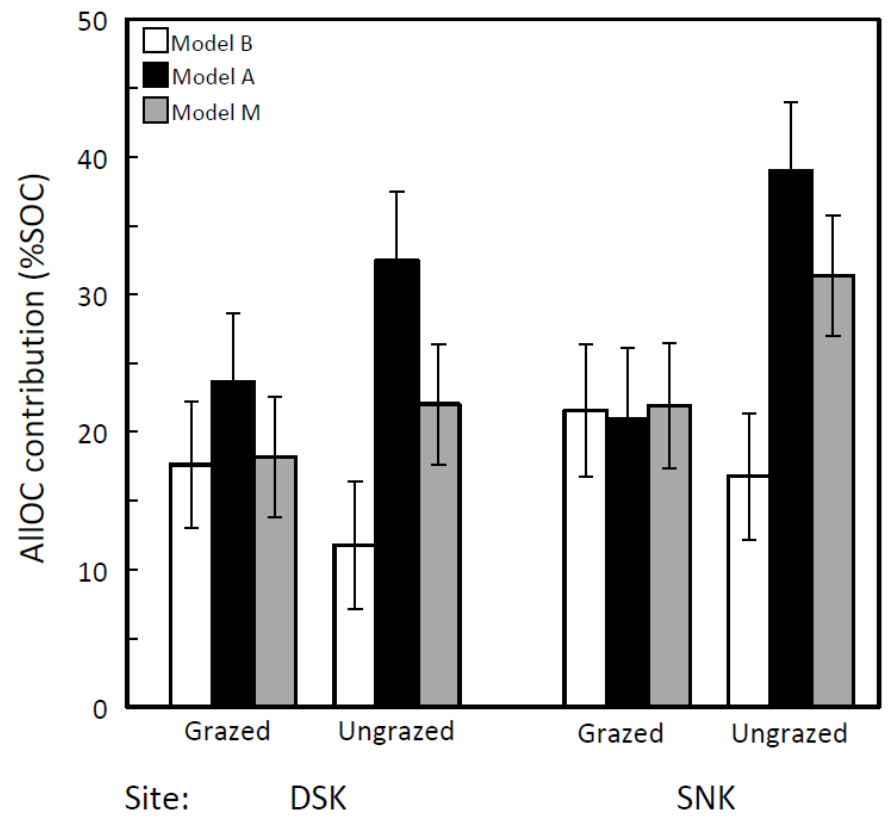

678 Figure 2 Allochthonous organic carbon (AllOC) contribution in percent of soil organic carbon $(\% \mathrm{SOC})$ in the topsoil of grazed und ungrazed treatments of two Wadden Sea saltmarsh sites, Dieksanderkoog (DSK) and Sönke-Nissen-Koog (SNK). Values presented are based on mixing-model calculations using three different end-member assumptions for the $\delta^{13} \mathrm{C}$ of autochthonous organic carbon: Model B ( $\delta^{13} \mathrm{C}$ of the belowground biomass), Model $\mathbf{A}\left(\delta^{13} \mathrm{C}\right.$ of the aboveground biomass), Model $\mathbf{M}$ (the calculated $\delta^{13} \mathrm{C}$ of a $1: 1$ mixed contribution of aboveground and belowground biomass). Values are means \pm SE. 

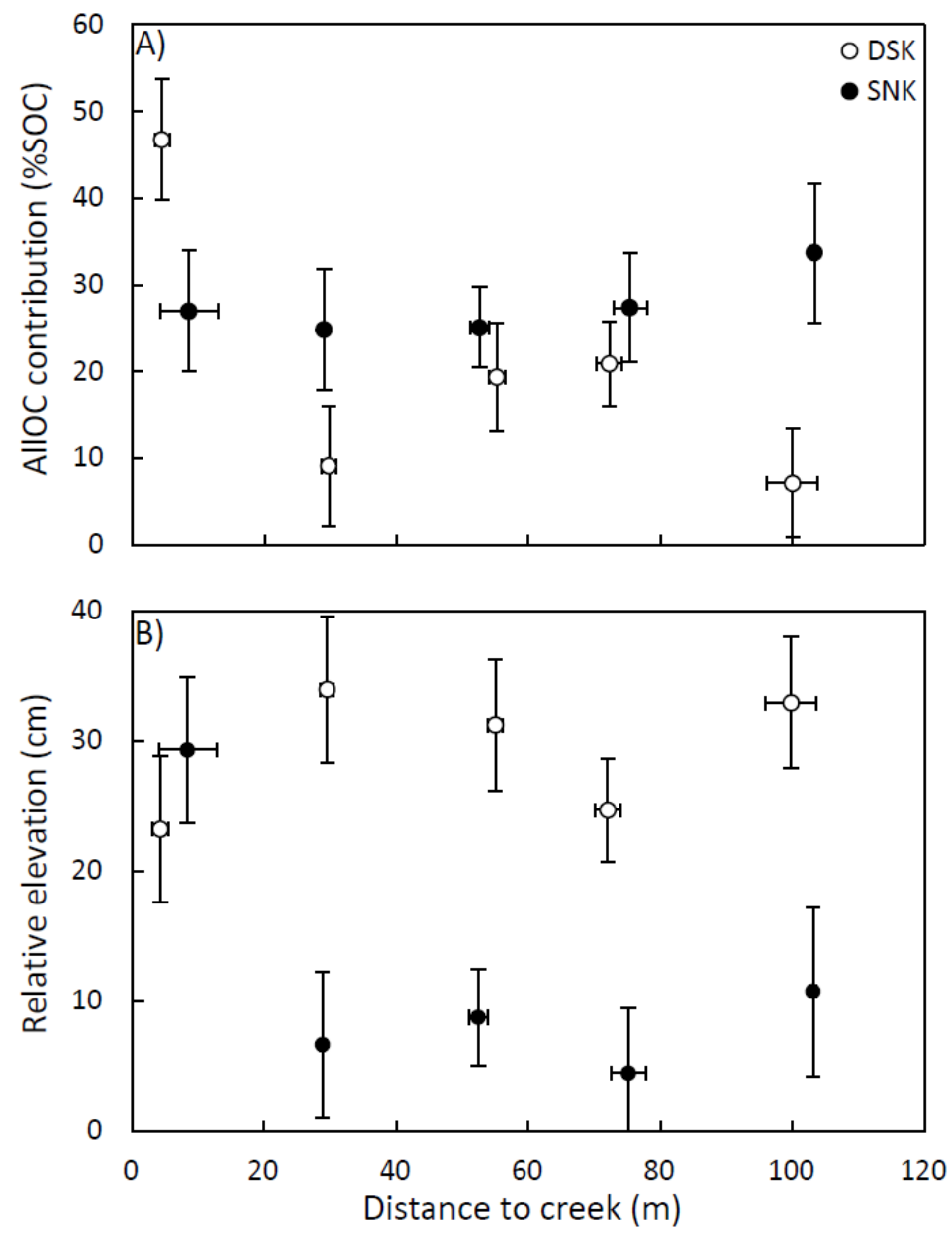

Figure 3 (A) Allochthonous organic carbon (AllOC) contribution [percentage of soil organic carbon (\%SOC)] in relation to distance to the creek in two Wadden Sea salt-marsh sites,

689 Dieksanderkoog (DSK) and Sönke-Nissen-Koog (SNK). Values are based on Model M (i.e. the calculated $\delta^{13} \mathrm{C}$ of a 1:1 mixed contribution of aboveground and belowground biomass was used for the $\delta^{13} \mathrm{C}$ of autochthonous organic carbon in mixing-model calculations). (B) Relative elevation of the sampling points in relation to distance to the creek in DSK and SNK. Values are means \pm SE. 

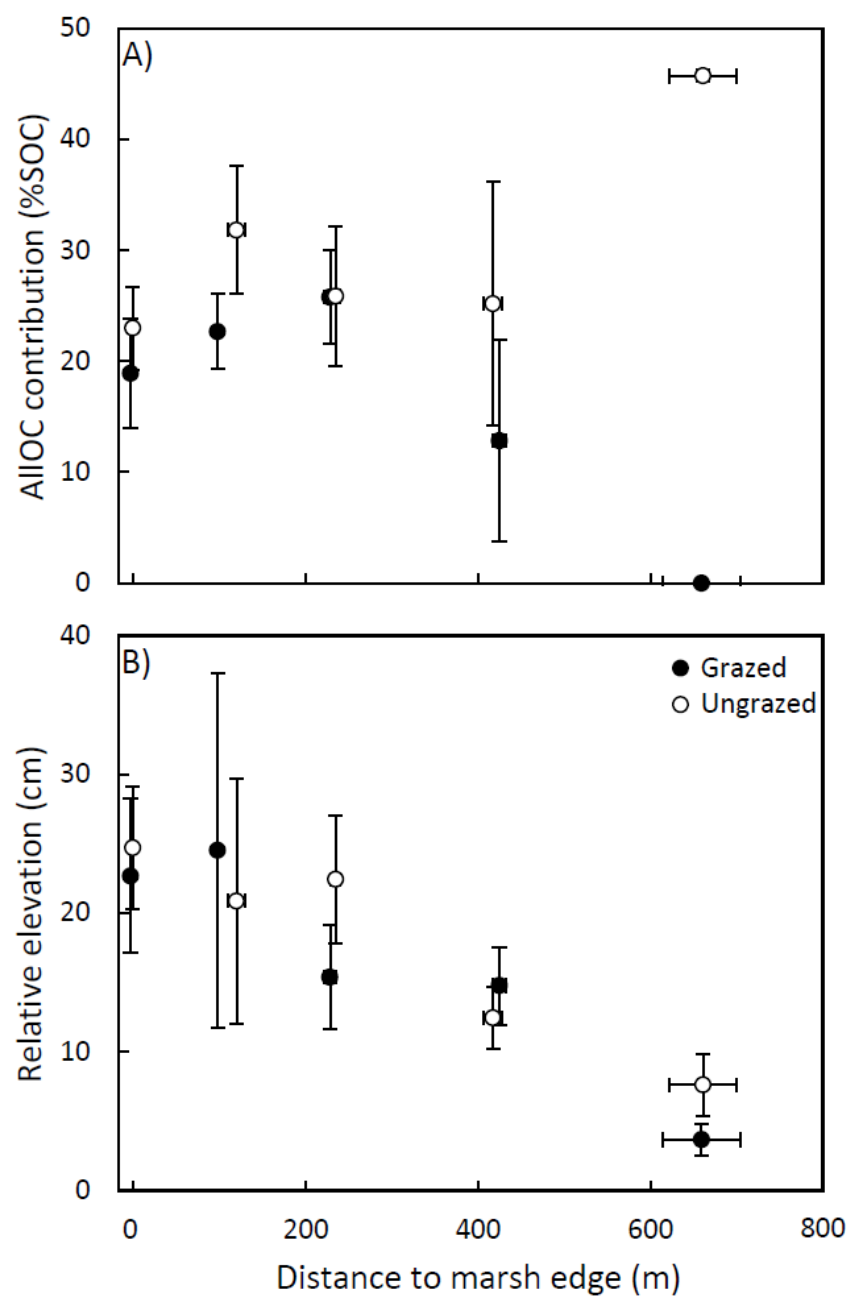

Figure 4 (A) Allochthonous organic carbon (AllOC) contribution [percentage of soil organic carbon $(\% \mathrm{SOC})]$ in relation to distance to the marsh edge in grazed vs. ungrazed treatments of two Wadden Sea salt-marsh sites. (B) Relative elevation of the sampling points in relation to distance to the marsh edge in. Values are means \pm SE, pooled by site.

701

702

703

704

705

706

707 
716

717

\section{TABLES}

Table $1 \delta^{13} \mathrm{C}$ of allochthonous and autochthonous OC sources (AllOC, AutOC) and topsoil samples in grazed und ungrazed treatments of two Wadden Sea salt-marsh sites. Values are means \pm SD given in $\delta$-notation versus Vienna PeeDee Belemnite $(\%)$. Values not connected by the same letter within one row are significantly different at $p<0.05$ based on Tukey's HSD tests.

\begin{tabular}{|c|c|c|c|c|}
\hline \multirow{2}{*}{ Sample material } & \multicolumn{2}{|c|}{ Dieksanderkoog (DSK) } & \multicolumn{2}{|c|}{ Sönke-Nissen-Koog (SNK) } \\
\hline & Grazed & Ungrazed & Grazed & Ungrazed \\
\hline Deposited sediment (AllOC) & $-24.29^{\mathrm{a}} \pm 0.42$ & $-24.14^{\mathrm{a}} \pm 0.26$ & $-23.08^{\mathrm{b}} \pm 0.20$ & $-23.12^{b} \pm 0.31$ \\
\hline \multicolumn{5}{|l|}{ Plant biomass (AutOC) } \\
\hline Aboveground & $-27.81^{\mathrm{a}} \pm 0.74$ & $-27.62^{\mathrm{a}, \mathrm{b}} \pm 0.76$ & $-26.86^{a, b} \pm 1.16$ & $-26.45^{b} \pm 1.58$ \\
\hline Belowground & $-27.38^{\mathrm{a}} \pm 1.16$ & $-26.60^{\mathrm{a}, \mathrm{b}} \pm 0.77$ & $-27.10^{\mathrm{a}} \pm 1.05$ & $-25.60^{\mathrm{b}} \pm 0.95$ \\
\hline 1:1 mixed & $-27.60^{\mathrm{a}} \pm 0.98$ & $-27.11^{\mathrm{a}} \pm 0.91$ & $-26.97^{\mathrm{a}} \pm 1.09$ & $-26.03^{b} \pm 1.35$ \\
\hline Topsoil & $-27.04^{\mathrm{a}} \pm 0.57$ & $-26.46^{\mathrm{a}, \mathrm{b}} \pm 0.59$ & $-25.94^{b} \pm 0.96$ & $-25.28^{b} \pm 0.58$ \\
\hline
\end{tabular}

Table 2 Results of ANCOVA analyses testing for effects of single and interacting factors on the allochthonous organic carbon contribution (percentage of soil organic carbon) to the topsoil of two Wadden Sea salt-marsh sites. ANCOVA analyses were run using three different end-member assumptions for the $\delta^{13} \mathrm{C}$ of autochthonous organic carbon in mixingmodel calculations: Model A $\left(\delta^{13} \mathrm{C}\right.$ of the aboveground biomass), Model $\mathbf{B}\left(\delta^{13} \mathrm{C}\right.$ of the belowground biomass), Model $\mathbf{M}$ (the calculated $\delta^{13} \mathrm{C}$ of a 1:1 mixed contribution of aboveground and belowground biomass). (-) indicates that factor dropped out of the ANCOVA model, ns. $=$ not significant.

\begin{tabular}{lrrrrrr}
\hline & \multicolumn{2}{c}{ Model A } & \multicolumn{2}{c}{ Model B } & \multicolumn{2}{c}{ Model M } \\
Factors & F value & $p$ value & $F$ value & $p$ value & F value & $p$ value \\
\hline Site & 0.28 & ns. & 1.07 & ns. & 2.93 & $<0.10$ \\
Treatment & 9.41 & $<\mathbf{0 . 0 1}$ & 1.58 & ns. & 2.82 & 0.10 \\
Distance to marsh edge & 0.01 & ns. & 0.03 & ns. & 0.08 & ns. \\
Distance to creek & 5.12 & $<\mathbf{0 . 0 5}$ & 0.46 & ns. & 2.93 & $<0.10$ \\
Relative elevation & & - & 3.07 & $<0.10$ & 4.14 & $<\mathbf{0 . 0 5}$ \\
Site x treatment & & - & & - & & - \\
Site x dist. marsh edge & & - & 3.51 & $<0.10$ & & - \\
Site x dist. creek & 9.21 & $<\mathbf{0 . 0 1}$ & & - & 4.27 & $<\mathbf{0 . 0 5}$ \\
Site x rel. elevation & & - & & - & & - \\
Treat. x dist. marsh edge & 5.71 & $<\mathbf{0 . 0 5}$ & 3.42 & $<0.10$ & 5.17 & $<\mathbf{0 . 0 5}$ \\
Treat. x dist. creek & & - & & - & & - \\
Treat. x rel. elevation & & - & 4.93 & $<\mathbf{0 . 0 5}$ & & - \\
Dist. marsh edge x dist. creek & & - & & - & & - \\
Dist. marsh edge x rel. elevation & & - & & - & & - \\
Dist. creek x rel. elevation & & - & & - & & - \\
\hline
\end{tabular}




\section{APPENDIX}

728 Appendix Table A1 Results of ANCOVA analyses testing for effects of single and 729 interacting factors on the $\delta^{13} \mathrm{C}$ of aboveground plant biomass, belowground plant biomass, 730 and mixed biomass (1:1 aboveground : belowground), referring to the three end-member 731 assumptions used in mixing-model calculations. (-) indicates that factor dropped out of the 732 ANCOVA model, ns. = not significant.

\begin{tabular}{|c|c|c|c|c|c|c|}
\hline \multirow[b]{2}{*}{ Factors } & \multicolumn{2}{|c|}{$\delta^{13} \mathrm{C}$ aboveground } & \multicolumn{2}{|c|}{$\delta^{13} \mathrm{C}$ belowground } & \multicolumn{2}{|c|}{$\delta^{13} \mathrm{C}$ mixed } \\
\hline & $F$ value & $p$ value & $F$ value & $p$ value & $F$ value & $p$ value \\
\hline Site & 11.42 & $<0.01$ & 6.45 & $<0.05$ & 16.03 & $<0.001$ \\
\hline Treatment & & - & 17.76 & $<0.001$ & 12.07 & $<0.01$ \\
\hline Distance to marsh edge & & - & 0.22 & ns. & 2.57 & ns. \\
\hline Distance to creek & & - & & - & & - \\
\hline Relative elevation & 1.65 & ns. & & - & & - \\
\hline Site $\mathrm{x}$ treatment & & - & & - & & - \\
\hline Site $\mathrm{x}$ dist. marsh edge & & - & 6.12 & $<0.05$ & & - \\
\hline Site $\mathrm{x}$ dist. creek & & - & & - & & - \\
\hline Site $\mathrm{x}$ rel. elevation & 3.86 & $<0.10$ & & - & 3.39 & $<0.10$ \\
\hline Treat. $\mathrm{x}$ dist. marsh edge & & - & & - & & - \\
\hline Treat. $\mathrm{x}$ dist. creek & & - & & - & & - \\
\hline Treat. $\mathrm{x}$ rel. elevation & & - & & - & & - \\
\hline Dist. marsh edge $\mathrm{x}$ dist. creek & & - & & - & & - \\
\hline Dist. marsh edge $\mathrm{x}$ rel. elevation & & - & & - & & - \\
\hline Dist. creek x rel. elevation & & - & & - & & - \\
\hline
\end{tabular}

